\title{
Optimising yeast as a host for recombinant protein production (review)
}

Nicklas Bonander ${ }^{1,2}$ and Roslyn $\mathrm{M} \mathrm{Bill}^{1 \dagger}$

${ }^{1}$ School of Life \& Health Sciences and Aston Research Centre for Healthy Ageing, Aston University, Birmingham B4 7ET, UK

${ }^{2}$ Department of Chemical and Biological Engineering, Chalmers University of Technology, SE-412 96 Gothenburg, Sweden

${ }^{\dagger}$ To whom correspondence should be addressed:

Dr Roslyn M Bill

Phone: +44 (0)121 2044274

E-mail: r.m.bill@aston.ac.uk 


\begin{abstract}
Having access to suitably stable, functional recombinant protein samples underpins diverse academic and industrial research efforts to understand the workings of the cell in health and disease. Synthesising a protein in recombinant host cells typically allows the isolation of the pure protein in quantities much higher than those found in the protein's native source. Yeast is a popular host as it is a eukaryote with similar synthetic machinery to the native human source cells of many proteins of interest, whilst also being quick, easy and cheap to grow and process. Even in these cells the production of some proteins can be plagued by low functional yields. We have identified molecular mechanisms and culture parameters underpinning high yields and have consolidated our findings to engineer improved yeast cell factories. In this chapter we provide an overview of the opportunities available to improve yeast as a host system for recombinant protein production.
\end{abstract}

Key Words: recombinant protein production; yeast; strain engineering; bioprocess control

\title{
1. Introduction
}

The development of recombinant protein production hosts that can be used to produce a wide range of targets is a key area of research (1). This is particularly true for the production of membrane proteins, which are high value targets in the drug discovery pipeline, and which cannot yet be produced in high yields in a predictable manner $(2,3)$. Yeast species, especially Pichia pastoris and Saccharomyces cerevisiae $(2,4-6)$ have already been identified as one of the most important components of a matrix of protein production hosts (7), and have contributed a substantial number of functional (8) recombinant eukaryotic membrane proteins in very high yields (e.g. (9)) thus enabling high resolution structure determination (10-13). 
Yeasts are well-characterised organisms and can be cultured very cheaply and easily in large quantities. They are also straightforward to manipulate genetically: publicly-available sequences are available for both $P$. pastoris (14) and $S$. cerevisiae (15). As yeasts are eukaryotes, they have protein-processing and post-translational modification mechanisms related to those found in mammalian cells. However, they contain ergosterol rather than cholesterol in their membranes and recombinant proteins produced using yeast may be decorated with high-mannose type sugars, which are not native to mammalian cells (2). Fortunately these problems have been overcome, in part, through strain engineering $(16,17)$. Despite these potential limitations, recombinant pharmaceuticals including insulin (18) and several vaccines (e.g. (19)) have all been produced in yeasts for commercial use, demonstrating their importance to the pharmaceutical industry. In order to optimise their productivity, two complimentary approaches have been taken: engineering the yeast strain and modifying the culture or 'bioprocess' conditions. Both are discussed in this chapter and are exemplified by studies on S. cerevisiae.

\section{Host cell engineering to increase recombinant protein yields}

Strategies to increase the recombinant protein productivity of host cells have been examined in both prokaryotic and eukaryotic cells. For example, a strain of Escherichia coli with high cardiolipin content (14\% compared with $3 \%$ in wild-type strains) has been found to produce increased yields of some proteins $(20,21)$. Lactococcus lactis has also been evolved to generate strains with modest improvements in their yield properties (22). In both cases mutations in the promoter system, and not in any in vivo cellular components of the translation or folding machinery, were found to have slowed the protein synthesis rate, presumably allowing the newly-synthesised protein to be accommodated into the endoplasmic reticulum with a minimum of inclusion body formation and cell death. 
We and others have used a more systematic approach (23-25) to optimise a host cell for recombinant protein production, with the specific goal of understanding the molecular barriers to achieving high yields. We therefore looked at the global host cell response to producing a membrane protein in S. cerevisiae (23). Using transcriptome arrays, we examined two different growth conditions that both led to relatively low protein yields (compared with normal conditions) and looked for changes in mRNAs that occurred in the same direction in both sets. This highlighted a set of genes, which was validated against those identified when comparing the single high-yielding growth condition with normal conditions. Genes that were down-regulated under low-yielding conditions were up-regulated under high-yielding conditions and vice versa (26). This allowed us to identify genes that influenced the yield per cell (27): three are known components of the transcriptional SAGA (GCN5 and SPT3) and mediator (SRB5) complexes, whilst a fourth, BMS1, is involved in ribosome biogenesis (26). Interestingly, there was an increase in BMS1 transcript number compared to wild-type in all our high-yielding host strains. In particular, we were able to tune the expression of BMS1 to maximise yields (26).

Work such as this has highlighted other relevant pathways for further study. For example in producing a recombinant membrane protein, there may be a benefit in altering the membrane lipid content in the host cell (25), as has been seen previously for E. coli strains (20, 21). Opi1 protein acts as a transcriptional suppressor, affecting the synthesis of phospholipids (28). An opi1s strain therefore contains increased phospholipid concentrations compared with wild-type strains (29). A study of strains with altered lipid composition in our own laboratory (e.g. opi1 $\Delta$, bio2 $\Delta$ and erg6 4 ) revealed that opi1 $\Delta$ yielded 8 times more protein than the corresponding wild-type strain (unpublished). Similar studies in P. pastoris on the 
global response to producing a recombinant protein (e.g. (30)) should soon lead to similar advances.

\section{Optimising culture conditions to increase recombinant protein yields}

Although the potential returns are high, engineering a host organism to increase recombinant protein yields can be expensive and time-consuming, especially if strategies are based on transcriptome analysis. An alternative, complimentary and potentially cheaper route is to optimise the experimental culture conditions, ideally using a statistical design of experiments approach (see Chapter 11). The development of growth media for mammalian cell culture has led the way in this area. For example, medium composition has been key to maintaining viable, high density cultures to obtain increased monoclonal antibody titres (31) or to be able to use chemically-defined serum-free medium $(32,33)$.

Variations in the composition of the culture medium, its $\mathrm{pH}$, its temperature, the availability of dissolved oxygen and the details of the induction regime (e.g. concentration of inducer, as well as the point and duration of induction) may all lead to improvements in the productivity of yeast cultures. For example, the yield of active G protein-coupled receptors (GPCRs) produced in $P$. pastoris was increased in over half the cases when the growth medium was supplemented with 2.5\% dimethyl sulfoxide (DMSO; 16 out of 20 ) or $0.04 \mathrm{mg} \mathrm{mL}^{-1} \mathrm{~L}$ histidine (12 out of 20) (34). However, in another study, the human tetraspanin protein, CD81, was produced and purified from $P$. pastoris (35), but supplementation with $2.5 \%$ DMSO did not increase yields (unpublished). Often, however, the induction regime in $P$. pastoris has a much greater effect on yield than the growth conditions (36). 
For cultivating $S$. cerevisiae, the most commonly-used media formulations in our laboratory are CBS (devised by the Centralbureau voor Schimmelcultures, the Netherlands; (37)) and those based on YNB (Yeast Nitrogen Base; (38)). YNB-based media are simpler to make than CBS, and originate from the work of Burkholder and Wickermann who used alterations in growth media to discriminate between yeast strains (39-41). For use with typical auxotrophic laboratory strains, both formulations require additional supplementation with an amino acid mixture, adenine and uracil (e.g. complete supplement mixture or CSM), as well as a carbon source (see Notes 1 and 2). Growth to medium cell densities $\left(\mathrm{OD}_{600}<50\right)$ is possible in $2 \times$ CBS medium supplemented with 20 or $50 \mathrm{~g} \mathrm{~L}^{-1}$ glucose as the carbon source $(42,43)$, while growth in a YNB-based medium typically yields less biomass and thus less recombinant protein. The use of alternative carbon sources, such as ethanol, has also been a route to increased protein yields (44). Overall, CBS medium supports a higher growth rate than YNB-based medium, but is much more labour intensive to prepare (23).

[Insert Table 1 here]

It has become clear in our own studies that YNB-based media are not ideal for protein production in S. cerevisiae (25). In order to combine the simplicity of the YNB-based formulation (see Note 1) with the improved performance of CBS medium (see Note 2), we have undertaken further optimisation studies. For example, since the membranes of the endoplasmic reticulum have a high content of phosphoinositol lipids, we examined the effect of supplementing a YNB-based medium with myo-inositol to the levels found in CBS (Table 1) on recombinant membrane protein yield. Initial data suggesting that yields were improved (unpublished) are consistent with our previous observations for the opi1 $\Delta$ strain, above, as well as literature reports suggesting that myo-inositol is essential for relieving some cellular 
stresses caused by recombinant membrane protein production (45). Furthermore, supplementation with myo-inositol (as well as biotin; Table 1) was found to increase growth rates to values typical of CBS medium. Adding both myo-inositol and biotin also increased the growth rate, but less dramatically (Figure 1). Addition of cobalt was found to decrease the growth rate even in the presence of myo-inositol and biotin, although in the presence of copper this decrease did not occur. Observations such as these could be followed up using a statistical design (46-48) to minimise the number of experiments required to examine all possible combinations of these medium components; especially as metal ion requirements for S. cerevisiae are often strain specific (49) (see Chapter 11).

[Insert Figure 1 here]

The beneficial effect of adding myo-inositol to YNB-based media on recombinant membrane protein yield may indicate that different medium components could be fine-tuned to relieve the stresses induced during recombinant soluble protein expression (50). For example induction of the unfolded protein response (51) might require a different balance of nutrient components. Adding only the required nutrients at just the right concentration for maximum productivity should enable this to be achieved in the most cost- and time-effective manner.

\section{Conclusions}

YNB-based media are quick and easy to make, but do not support optimal recombinant protein yields. Supplementing the formulation with additional myo-inositol and biotin may overcome these limitations. This is especially true for recombinant membrane proteins.

\section{Notes}


1. A YNB-based medium for a strain with a given auxotrophy is composed of $1.7 \mathrm{~g} \mathrm{~L}^{-1}$ YNB (without ammonium sulphate and amino acids, BIO101 \#4027-012), $5 \mathrm{~g} \mathrm{~L}^{-1}$ ammonium sulphate and CSM minus the relevant component, as directed by the manufacturer (BIO101 \#4510-333). Glucose is autoclaved separately as a 20\% stock solution and added to a final concentration of $2 \%$. If the glucose is autoclaved together with the ammonium sulphate and YNB, the solution will have a yellowish appearance. At a final $\mathrm{OD}_{600}<15$ this will not affect growth, but it is quite probable that nutrient limitation events will occur when growing to higher densities (using e.g. 5\% glucose), due to glucose-induced reactions during autoclaving of the nutrients together. It is generally considered that the maximum glucose concentration that a YNB-based medium will support is 5\%; at higher glucose concentrations, for example in a fedbatch culture, additional nutrients should be provided.

2. $2 \times$ CBS medium is composed of $10 \mathrm{~g} \mathrm{~L}^{-1}$ ammonium sulphate, $6 \mathrm{~g} \mathrm{~L}^{-1}$ potassium dihydrogen phosphate, $1 \mathrm{~g} \mathrm{~L}^{-1}$ magnesium sulphate heptahydrate plus twice the amount of CSM minus the relevant component directed (BIO101 \#4510-333). Glucose is autoclaved separately as a $20 \%$ stock solution and added to a final concentration of $2 \%$. Finally, $2 \mathrm{~mL} \mathrm{~L}^{-1}$ each of trace element solution and vitamin stock solution are added. 1 $\mathrm{L}$ trace element solution is composed of the following: $15 \mathrm{~g}$ EDTA, $4.5 \mathrm{~g} \mathrm{ZnSO}_{4} \cdot 7 \mathrm{H}_{2} 0$, $1 \mathrm{~g} \mathrm{MnCl}_{2} \cdot 4 \mathrm{H}_{2} \mathrm{O}, 0.3 \mathrm{~g} \mathrm{CoCl}_{2} \cdot 6 \mathrm{H}_{2} \mathrm{O}, 0.3 \mathrm{~g} \mathrm{CuSO}_{4} \cdot 5 \mathrm{H}_{2} \mathrm{O}, 0.4 \mathrm{~g} \mathrm{Na}_{2} \mathrm{MoO}_{4} \cdot 2 \mathrm{H}_{2} \mathrm{O}, 4.5 \mathrm{~g}$ $\mathrm{CaCl}_{2} \cdot 2 \mathrm{H}_{2} \mathrm{O}, 3 \mathrm{~g} \mathrm{FeSO}_{4} \cdot 7 \mathrm{H}_{2} \mathrm{O}, 1 \mathrm{~g} \mathrm{H}_{3} \mathrm{BO}_{3}$ and $0.1 \mathrm{~g} \mathrm{KI}$. The $\mathrm{pH}$ is maintained at 6.0 with $1 \mathrm{M} \mathrm{NaOH}$ throughout the addition and finally adjusted to $\mathrm{pH} 4$ with $1 \mathrm{M} \mathrm{HCl}$ prior to autoclave sterilisation and storage at $4^{\circ} \mathrm{C}$ in the dark. $1 \mathrm{~L}$ vitamin solution is composed of the following: $0.05 \mathrm{~g}$ biotin, $1 \mathrm{~g}$ calcium D-panthothenate, $1 \mathrm{~g}$ nicotinic acid, $25 \mathrm{~g}$ myo-inositol, $1 \mathrm{~g}$ thiamine hydrochloride, $1 \mathrm{~g}$ pyridoxol hydrochloride and $0.2 \mathrm{~g}$ D- 
amino benzoic acid. The $\mathrm{pH}$ is maintained at 6.5 with $1 \mathrm{M} \mathrm{HCl}$. The vitamin solution is filter-sterilised and stored as $20 \mathrm{~mL}$ aliquots at $4^{\circ} \mathrm{C}$.

\section{Acknowledgements}

This work was supported by the European Commission via contract LSHG-CT-2004-504601 (E-MeP), LSHG-CT-2006-037793 (OptiCryst) and Grant 201924 (EDICT) to RMB. The BBSRC supports bioreactors and a flow microcalorimeter in the RMB Laboratory through an REI award. 


\section{References}

1. Bill, R. M., Henderson, P. J., Iwata, S., Kunji, E. R., Michel, H., Neutze, R., Newstead, S., Poolman, B., Tate, C. G. and Vogel, H. (2011) Overcoming barriers to membrane protein structure determination, Nat Biotechnol 29, 335-340.

2. Bill, R. M. (2001) Yeast - a panacea for the structure-function analysis of membrane proteins? Curr Genet 40, 157-171.

3. Grisshammer, R. and Tate, C. G. (1995) Overexpression of integral membrane proteins for structural studies, Q Rev Biophys 28, 315-422.

4. Gelperin, D. M., White, M. A., Wilkinson, M. L., Kon, Y., Kung, L. A., Wise, K. J., Lopez-Hoyo, N., Jiang, L., Piccirillo, S., Yu, H., Gerstein, M., Dumont, M. E., Phizicky, E. M., Snyder, M. and Grayhack, E. J. (2005) Biochemical and genetic analysis of the yeast proteome with a movable ORF collection, Genes Dev 19, 28162826.

5. Reilander, H. and Weiss, H. M. (1998) Production of G-protein-coupled receptors in yeast, Curr Opin Biotechnol 9, 510-517.

6. Sarramegna, V., Talmont, F., Demange, P. and Milon, A. (2003) Heterologous expression of G-protein-coupled receptors: comparison of expression systems fron the standpoint of large-scale production and purification, Cell Mol Life Sci 60, 15291546.

7. Freigassner, M., Pichler, H. and Glieder, A. (2009) Tuning microbial hosts for membrane protein production, Microb Cell Fact 8, 69.

8. Karlgren, S., Pettersson, N., Nordlander, B., Mathai, J. C., Brodsky, J. L., Zeidel, M. L., Bill, R. M. and Hohmann, S. (2005) Conditional osmotic stress in yeast: a system to study transport through aquaglyceroporins and osmostress signaling, J Biol Chem 280, 7186-7193. 
9. Nyblom, M., Oberg, F., Lindkvist-Petersson, K., Hallgren, K., Findlay, H., Wikstrom, J., Karlsson, A., Hansson, O., Booth, P. J., Bill, R. M., Neutze, R. and Hedfalk, K. (2007) Exceptional overproduction of a functional human membrane protein, Protein Expr Purif 56, 110-120.

10. Jidenko, M., Nielsen, R. C., Sorensen, T. L., Moller, J. V., le Maire, M., Nissen, P. and Jaxel, C. (2005) Crystallization of a mammalian membrane protein overexpressed in Saccharomyces cerevisiae, Proc Natl Acad Sci U S A 102, 11687-11691.

11. Long, S. B., Campbell, E. B. and Mackinnon, R. (2005) Crystal structure of a mammalian voltage-dependent Shaker family $\mathrm{K}^{+}$channel, Science 309, 897-903.

12. Tornroth-Horsefield, S., Wang, Y., Hedfalk, K., Johanson, U., Karlsson, M., Tajkhorshid, E., Neutze, R. and Kjellbom, P. (2006) Structural mechanism of plant aquaporin gating, Nature 439, 688-694.

13. Horsefield, R., Norden, K., Fellert, M., Backmark, A., Tornroth-Horsefield, S., Terwisscha van Scheltinga, A. C., Kvassman, J., Kjellbom, P., Johanson, U. and Neutze, R. (2008) High-resolution x-ray structure of human aquaporin 5, Proc Natl Acad Sci U S A 105, 13327-13332.

14. De Schutter, K., Lin, Y. C., Tiels, P., Van Hecke, A., Glinka, S., Weber-Lehmann, J., Rouze, P., Van de Peer, Y. and Callewaert, N. (2009) Genome sequence of the recombinant protein production host Pichia pastoris, Nat Biotechnol 27, 561-566.

15. Goffeau, A., Barrell, B. G., Bussey, H., Davis, R. W., Dujon, B., Feldmann, H., Galibert, F., Hoheisel, J. D., Jacq, C., Johnston, M., Louis, E. J., Mewes, H. W., Murakami, Y., Philippsen, P., Tettelin, H. and Oliver, S. G. (1996) Life with 6000 genes, Science 274, 546, 563-547.

16. Hamilton, S. R., Bobrowicz, P., Bobrowicz, B., Davidson, R. C., Li, H., Mitchell, T., Nett, J. H., Rausch, S., Stadheim, T. A., Wischnewski, H., Wildt, S. and Gerngross, T. 
U. (2003) Production of complex human glycoproteins in yeast, Science 301, 12441246.

17. Hamilton, S. R. and Gerngross, T. U. (2007) Glycosylation engineering in yeast: the advent of fully humanized yeast, Curr Opin Biotechnol 18, 387-392.

18. Kjeldsen, T., Ludvigsen, S., Diers, I., Balschmidt, P., Sørensen, A. R. and Kaarsholm, N. C. (2002) Engineering-enhanced protein secretory expression in yeast with application to insulin, J Biol Chem 277, 18245-18248.

19. Siddiqui, M. A. A. and Perry, C. M. (2006) Human papillomavirus quadrivalent (types 6, 11, 16, 18) recombinant vaccine (Gardasil (R)), Drugs 66, 1263-1271.

20. Miroux, B. and Walker, J. E. (1996) Over-production of proteins in Escherichia coli: mutant hosts that allow synthesis of some membrane proteins and globular proteins at high levels, J Mol Biol 260, 289-298.

21. Arechaga, I., Miroux, B., Karrasch, S., Huijbregts, R., de Kruijff, B., Runswick, M. J. and Walker, J. E. (2000) Characterisation of new intracellular membranes in Escherichia coli accompanying large scale over-production of the b subunit of F(1)F(o) ATP synthase, FEBS Lett 482, 215-219.

22. Linares, D. M., Geertsma, E. R. and Poolman, B. (2010) Evolved Lactococcus lactis strains for enhanced expression of recombinant membrane proteins, $J \mathrm{Mol} \mathrm{Biol} \mathbf{4 0 1}$, 45-55.

23. Bonander, N., Hedfalk, K., Larsson, C., Mostad, P., Chang, C., Gustafsson, L. and Bill, R. M. (2005) Design of improved membrane protein production experiments: Quantitation of the host response, Protein Science 14, 1729-1740.

24. Griffith, D. A., Delipala, C., Leadsham, J., Jarvis, S. M. and Oesterhelt, D. (2003) A novel yeast expression system for the overproduction of quality-controlled membrane proteins, FEBS Lett 553, 45-50. 
25. Bonander, N. and Bill, R. M. (2009) Relieving the first bottleneck in the drug discovery pipeline: using array technologies to rationalize membrane protein production, Expert Rev Proteomics 6, 501-505.

26. Bonander, N., Darby, R. A., Grgic, L., Bora, N., Wen, J., Brogna, S., Poyner, D. R., O'Neill, M. A. and Bill, R. M. (2009) Altering the ribosomal subunit ratio in yeast maximizes recombinant protein yield, Microb Cell Fact 8, 10.

27. Bawa, Z., Bland, C. E., Bonander, N., Bora, N., Cartwright, S. P., Clare, M., Conner, M. T., Darby, R. A., Dilworth, M. V., Holmes, W. J., Jamshad, M., Routledge, S. J., Gross, S. R. and Bill, R. M. (2011) Understanding the yeast host cell response to recombinant membrane protein production, Biochem Soc Trans 39, 1113.

28. Santiago, T. C. and Mamoun, C. B. (2003) Genome expression analysis in yeast reveals novel transcriptional regulation by inositol and choline and new regulatory functions for Opi1p, Ino2p and Ino4p, J Biol Chem 278, 38723-38730.

29. Jiranek, V., Graves, J. A. and Henry, S. A. (1998) Pleiotropic effects of the opi1 regulatory mutation of yeast: its effects on growth and on phospholipid and inositol metabolism, Microbiology 144, 2739-2748.

30. Sohn, S. B., Graf, A. B., Kim, T. Y., Gasser, B., Maurer, M., Ferrer, P., Mattanovich, D. and Lee, S. Y. (2010) Genome-scale metabolic model of methylotrophic yeast Pichia pastoris and its use for in silico analysis of heterologous protein production, Biotechnol J 5, 705-715.

31. De Alwis, D. M., Dutton, R. L., Scharer, J. and Moo-Young, M. (2007) Statistical methods in media optimization for batch and fed-batch animal cell culture, Bioprocess Biosyst Eng 30, 107-113.

32. Stiens, L. R., Buntemeyer, H., Lutkemeyer, D., Lehmann, J., Bergmann, A. and Weglohner, W. (2000) Development of serum-free bioreactor production of 
recombinant human thyroid stimulating hormone receptor, Biotechnol Prog 16, 703709.

33. van der Valk, J., Brunner, D., De Smet, K., Fex Svenningsen, A., Honegger, P., Knudsen, L. E., Lindl, T., Noraberg, J., Price, A., Scarino, M. L. and Gstraunthaler, G. (2010) Optimization of chemically defined cell culture media- replacing fetal bovine serum in mammalian in vitro methods, Toxicol in vitro 24, 1053-1063.

34. Andre, N., Cherouati, N., Prual, C., Steffan, T., Zeder-Lutz, G., Magnin, T., Pattus, F., Michel, H., Wagner, R. and Reinhart, C. (2006) Enhancing functional production of G protein-coupled receptors in Pichia pastoris to levels required for structural studies via a single expression screen, Protein Sci 15, 1115-1126.

35. Bonander, N., Jamshad, M., Hu, K., Farquhar, M. J., Stamataki, Z., Balfe, P., McKeating, J. A. and Bill, R. M. (2011) Structural characterization of CD81-Claudin1 hepatitis C virus receptor complexes, Biochem Soc Trans 39, 537-540.

36. Holmes, W. J., Darby, R. A., Wilks, M. D., Smith, R. and Bill, R. M. (2009) Developing a scalable model of recombinant protein yield from Pichia pastoris: the influence of culture conditions, biomass and induction regime, Microb Cell Fact 8 , 35.

37. Verduyn, C., Postma, E., Scheffers, W. A. and Van Dijken, J. P. (1992) Effect of benzoic acid on metabolic fluxes in yeasts: a continuous-culture study on the regulation of respiration and alcoholic fermentation, Yeast 8, 501-517.

38. Abelovska, L., Bujdos, M., Kubova, J., Petrezselyova, S., Nosek, J. and Tomaska, L. (2007) Comparison of element levels in minimal and complex yeast media, Can J Microbiol 53, 533-535.

39. Burkholder, P. R., McVeigh, I. and Moyer, D. (1944) Studies on some growth factors of yeasts, J Bacteriol 48, 385-391. 
40. Wickerham, L. J. (1946) A critical evaluation of the nitrogen assimilation tests commonly used in the classification of yeasts, J Bacteriol 52, 293-301.

41. Wickerman, L. J. (1951) Taxonomy of yeasts, U S Dept Agri Tech Bull 1029, 1-56.

42. Henricsson, C., de Jesus Ferreira, M. C., Hedfalk, K., Elbing, K., Larsson, C., Bill, R. M., Norbeck, J., Hohmann, S. and Gustafsson, L. (2005) Engineering of a novel Saccharomyces cerevisiae wine strain with a respiratory phenotype at high external glucose concentrations, Appl Environ Microbiol 71, 6185-6192.

43. Ferndahl, C., Bonander, N., Logez, C., Wagner, R., Gustafsson, L., Larsson, C., Hedfalk, K., Darby, R. A. and Bill, R. M. (2010) Increasing cell biomass in Saccharomyces cerevisiae increases recombinant protein yield: the use of a respiratory strain as a microbial cell factory, Microb Cell Fact 9, 47.

44. van de Laar, T., Visser, C., Holster, M., Lopez, C. G., Kreuning, D., Sierkstra, L., Lindner, N. and Verrips, T. (2007) Increased heterologous protein production by Saccharomyces cerevisiae growing on ethanol as sole carbon source, Biotechnol Bioeng 96, 483-494.

45. Gaspar, M. L., Aregullin, M. A., Jesch, S. A. and Henry, S. A. (2006) Inositol induces a profound alteration in the pattern and rate of synthesis and turnover of membrane lipids in Saccharomyces cerevisiae, J Biol Chem 281, 22773-22785.

46. Weuster-Botz, D. (2000) Experimental design for fermentation media development: statistical design or global random search?, J Biosci Bioeng 90, 473-483.

47. Rezessy-Szabo, J. M., Nguyen, Q. D. and Hoschke, A. (2000) Optimisation of composition of media for the production of amylolytic enzymes by Thermomyces lanuginosus ATCC 34626, Food Technol Biotechnol 38, 229-234.

48. Ratnam, B. V. V., Subba Rao, S., Mendu, D. R., Narasimha Rao, M. and Ayyanna, C. (2005) Optimization of medium constituents and fermentation conditions for the 
production of ethanol from palmyra jaggery using response surface methodology, World J Microbiol Biotechnol, 21, 399-404.

49. Olson, B. H. and Johnson, M. J. (1949) Factors producing high yeast yields in synthetic media, J Bacteriol 57, 235-246.

50. Gasser, B., Maurer, M., Gach, J., Kunert, R. and Mattanovich, D. (2006) Engineering of Pichia pastoris for improved production of antibody fragments, Biotechnol Bioeng 94, 353-361.

51. Travers, K. J., Patil, C. K., Wodicka, L., Lockhart, D. J., Weissman, J. S. and Walter, P. (2000) Functional and genomic analyses reveal an essential coordination between the unfolded protein response and ER-associated degradation, Cell 101, 249-258.

52. Perlman, D. and O'Brien, E. (1954) Characteristics of a cobalt tolerant culture of Saccharomyces cerevisiae, J Bacteriol 68, 167-170.

53. Bennett, A., Rowe, R. I., Soch, N. and Eckhert, C. D. (1999) Boron stimulates yeast (Saccharomyces cerevisiae) growth, J Nutr 129, 2236-2238. 


\section{Figure legend}

Figure 1: Specific growth rates for S. cerevisiae strain BY4741 producing recombinant Fps1. The specific growth rate $\left(\mu ; \mathrm{h}^{-1}\right)$ was computed using the amount of base added in two adjacent 20 min segments in the 2-14 g L ${ }^{-1}$ residual glucose range (23). The average dry weight after consumption of the carbon source (at $55 \mathrm{~h}$ ) was $0.17 \mathrm{~g}$ biomass (g glucose) ${ }^{-1}$. This value increased by $0.04 \mathrm{~g} \mathrm{~g}^{-1}$ in the presence of myo-inositol and biotin. Media additions to YNB are as follows: myo-inositol (open squares); biotin (open diamonds); myo-inositol/ biotin/zinc/cobalt (filled squares); myo-inositol/biotin (open triangles); myoinositol/biotin/zinc/cobalt/copper (crosses); myo-inositol/ biotin/zinc (open circles). YNB alone is shown as a large filled circle. $2 \times$ CBS is shown as a large open circle. Individual dry weight values $\left(\mathrm{g} \mathrm{g}^{-1}\right)$ are listed in parenthesis after each condition $(\mathrm{n}=2$; standard deviation $<$ 0.008 for all data points). 
Table 1: Comparison of selected nutrient components in media based on CBS and YNB formulations.

\begin{tabular}{|l|c|c|c|}
\hline Nutrient & $\begin{array}{c}\text { CBS } \\
\mathbf{( m g ~ L ~}^{-1} \text { ) }\end{array}$ & $\begin{array}{c}\text { YNB } \\
\mathbf{( m g ~ L ~}^{-1} \text { ) }\end{array}$ & $\begin{array}{c}\text { Factor difference } \\
\text { (CBS:YNB) }\end{array}$ \\
\hline Biotin & 0.05 & 0.002 & 25 \\
\hline myo-inositol & 25 & 2 & 12.5 \\
\hline Cobalt chloride hexahydrate & 0.3 & 0 & 11.25 \\
\hline Zinc sulphate heptahydrate & 4.5 & 0.4 & 7.5 \\
\hline Copper sulphate pentahydrate & 0.3 & 0.062 & $\infty$ \\
\hline
\end{tabular}

S. cerevisiae requires a minimum concentration of $\mathrm{Cu}^{2+}, \mathrm{Zn}^{2+}$ and $\mathrm{Fe}^{2+}$ of 15,200 and $150 \mu \mathrm{g}$ $\mathrm{L}^{-1}$, respectively (49). In YNB-based media these concentrations are typically 16, 91 and 88 $\mu \mathrm{g} \mathrm{L}^{-1}$, respectively, and in CBS they are 76, 1,023 and $602 \mu \mathrm{g} \mathrm{L}^{-1}$, respectively. Other metal ions not included in the YNB formulation are $\mathrm{Co}^{2+}$ and $\mathrm{Ni}^{2+}$. Cobalt in particular is known to have an inhibitory effect on growth (52). Boric acid is present in YNB-based formulations at a concentration of $500 \mu \mathrm{g} \mathrm{L} \mathrm{L}^{-1}(8 \mu \mathrm{M})$ and is known to increase biomass yields during respiratory growth at $150 \mu \mathrm{M}$ (53). The five nutrients with the largest difference in concentration between CBS and YNB media are listed. 


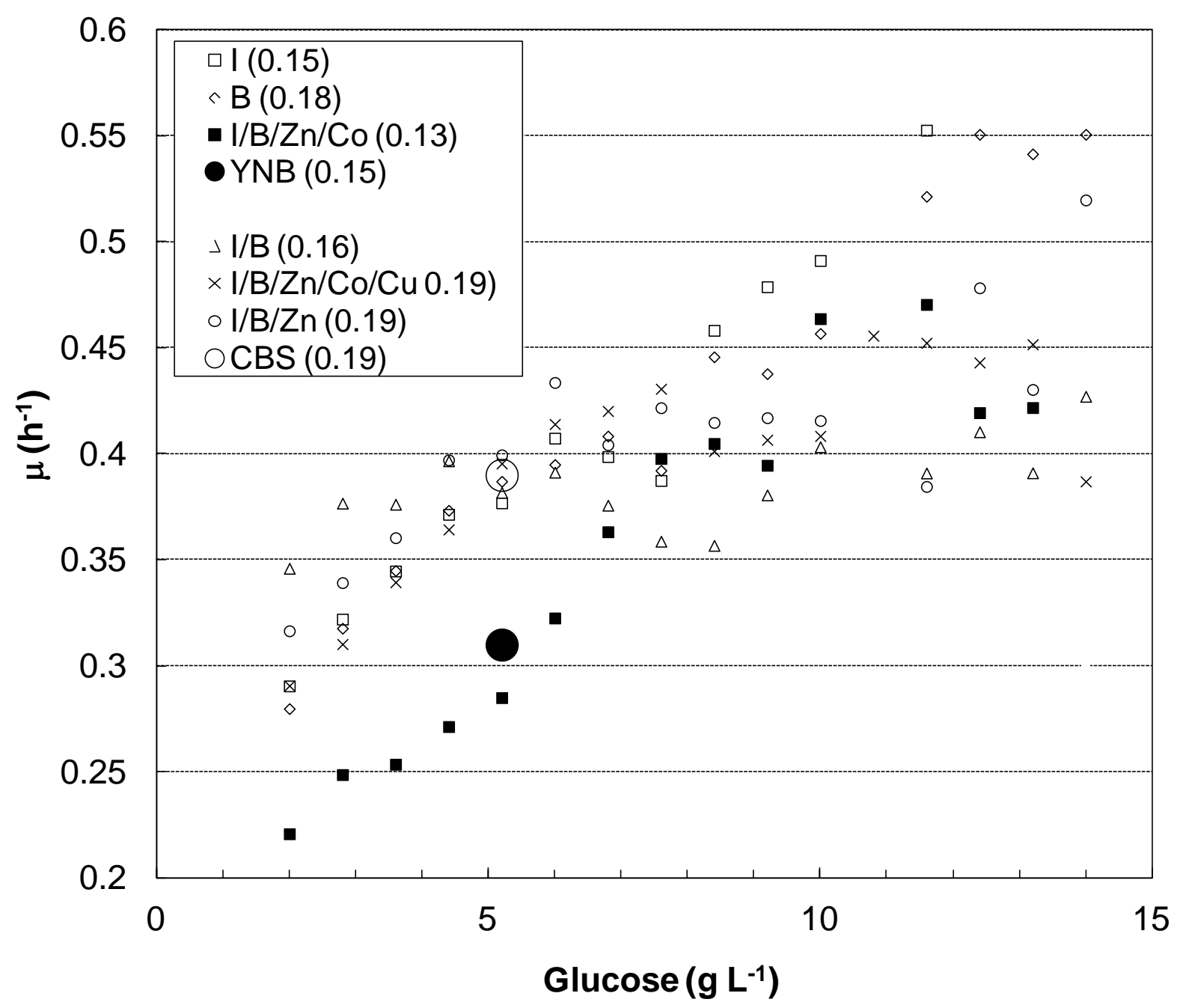

